\title{
sciendo
}

\author{
Current Issues in Pharmacy and Medical Sciences
}

Formerly ANNALES UNIVERSITATIS MARIAE CURIE-SKIODOWSKA, SECTIO DDD, PHARMACIA

journal homepage: http://www.curipms.umlub.pl/

\section{The mechanism of action of platelet-rich plasma - composition analysis and safety assessment}

\author{
Anna Maria Lichtarska ${ }^{\circledR}$, Malgorzata Maria Sokol*(i) \\ Department of Cosmetology, Faculty of Medicine, University of Information Technology and Management in Rzeszow, Poland
}

\section{INFO}

Received 31 March 2021

Accepted: 30 September 2021

\section{Keywords:}

platelet-rich plasma,

PRP,

platelets,

skin regeneration,

aesthetic medicine,

growth factors.

\begin{abstract}
Aesthetic medicine is an intensively developing field, more and more focused on stimulating and regenerating the skin, rather than on emergency treatment. There are many methods used by doctors for biostimulating therapies, but the most popular procedure in recent years is the implantation of platelet-rich plasma (PRP) used to date successfully in ophthalmology, dermatology, surgery, dentistry and even in orthopedics. The procedure uses autologous material, and its essence is a repair action on damaged cells of the patient as well as the activation of healthy cells and their stimulation for more effective work. The aim of the paper is to present current knowledge about platelet-rich plasma therapy in anti-aging treatment, the effectiveness of therapy with its use, and the mechanism and safety of PRP. The composition of the autologous preparation and its use in aesthetic medicine were also analyzed.

PRP is a procedure that uses the patient's own cells, and growth factors are of key importance in the process of skin regeneration and biostimulation. The correctly performed procedure, including the appropriate collection and administration of a buffy coat to the patient and compliance with all the rules of sterility, results in positive effects of the therapy. Numerous studies prove the effectiveness and safety of the platelet-rich plasma treatment.

Highly concentrated platelets in the deposited preparation stimulate the surrounding cells to angiogenesis, differentiation, proliferation and synthesis of components essential for remodeling of the treated area. The therapy is highly effective and safe to use.
\end{abstract}

\section{INTRODUCTION}

The constant rush for youth initiates the emergence of newer and newer methods of delaying the aging process of the skin, while maintaining the highest degree of safety of the treatment. The current trend is to stimulate regenerative processes in place of the practiced implantation of synthetic substitutes, and one of the most popular treatments is the so-called "platelet-rich plasma" (PRP, Platelet Rich Plasma). An autologous blood product is used here which contains concentrated platelets (PLT, Platelets) suspended in a small volume of plasma. The material is own, obtained from the patient and its use has become very popular in aesthetic, regenerative and reconstructive medicine [1,2]. In recent years, the material has been enthusiastically used to regenerate tissues, to stimulate cell renewal and elements of the dermis so that they can function without losing their basic functions. It has a biostimulating, stimulating and

\footnotetext{
* Corresponding author

e-mail: msokol@wsiz.edu.pl
}

regenerating effect on older and damaged cells, and over the past 20 years, it has gained popularity and continues to arouse interest among doctors and scientists [3].

The work is a review based on a collection of specialist literature in the field of aesthetic medicine concerning platelet-rich plasma. We carried out a comprehensive analysis and comparison of the results of scientific papers published in 2012-2019. The casuistic element introduced to this paper was made possible courtesy of the cooperation with the specialist office Twój Kosmetolog Agnieszka Łukaszewska, thanks to which it was possible to take photos and utilize them in the further part of the study.

\section{AIM}

The main aim of the study is to present current knowledge about the autologous preparation that is characterized by the natural regenerative capacity of tissues of the human body, and data on the safety of using a treatment with own material. In addition, we described the effectiveness 
of the therapy and the mechanism of action of the administered preparation. We also proffered information on the recent wide application of platelet-rich plasma in aesthetic medicine.

\section{DESCRIPTION OF THE STATE OF KNOWLEDGE}

\section{Preparation of autologous material}

Autologous platelet-rich plasma is a platelet concentrate preparation obtained from the patient's peripheral blood. The blood consists of liquid plasma - about 55\% of its volume, the rest are morphotic blood elements, and the plasma consists of water, proteins, fats, hormones, vitamins, glucose, minerals and other metabolic products and nutrients. In medical practice, there are many methods available to obtain the preparation needed for the procedure, which is always obtained directly from the patient undergoing the treatment. The feature common to all methods is the attempt to reverse the ratio of red blood cells to platelets in relation to peripheral whole blood. A clearly demarcated PLT concentrate from morphotic blood elements is then obtained [4]. The condition for the effective conduct of the procedure is to meet the sterility requirements and to choose the appropriate specialized centrifuge. This is important so that platelets be able to perform their functions [5]. Before the procedure, there are two parameters to be considered that indicate that it is to be well-performed. One is percent platelet recovery, i.e. the platelet count ready to be administered to the patient compared to the platelet count in the patient's blood collected in the initial phase. The other is the concentration of the platelets, which indicates the amount of plasma in which they are suspended. Greater dilution of the preparation with plasma results in a decrease in the regenerative properties of the prepared autologous material $[3,6,7]$.

The specialist who performs the procedure begins by collecting blood into a test tube containing sodium citrate - used as an anticoagulant - so that the collected blood will not clot [3-7].

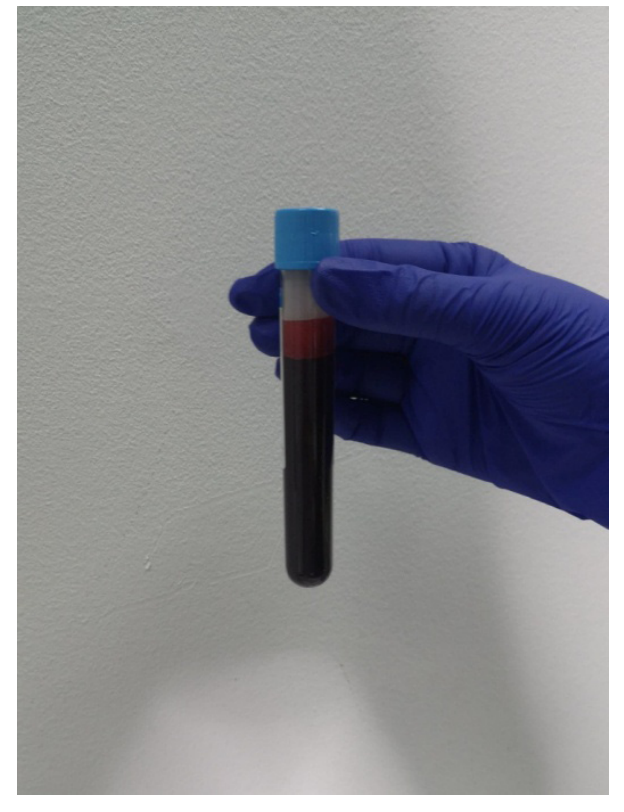

Source: own study

Figure 1. The patient's collected blood placed in a test tube
All stages of preparation of the treatment material, including the amount of blood collected (from 9 to $120 \mathrm{ml}$ ), depend on the manufacturer of the equipment, the specialist performing the procedure and on indications for therapy [1]. The amount of blood collected depends primarily on the size of the area covered by the treatment - less blood is needed for the face (about $20 \mathrm{ml}$ ) than for the face, neck, and décolleté area [4]. Subsequently, with the use of a centrifuge, the fraction obtained from the venous blood is separated by thrombophoresis [8]. The procedure consists in centrifugation at the speed, time and number of repetitions recommended by the manufacturer of the device, which affects the qualitative and quantitative composition of the plasma. By way of appropriate centrifugation parameters, it is possible to separate the platelet concentrate under the influence of centrifugal force and in accordance with the rules of physics - heavier products sink to the bottom $[3,4,6,8]$. After centrifugation, there are three separate layers in the tube. The first - the heaviest - is the erythrocyte fraction, the second - the middle - is platelet-rich plasma (platelets), and the third, or upper layer, is platelet poor plasma, called PPP (Platelet Poor Plasma). Particular fractions are separated from each other manually by pipetting or, via sedimentation gel, by partitions in the form of a buoy or a float $[4,8]$.

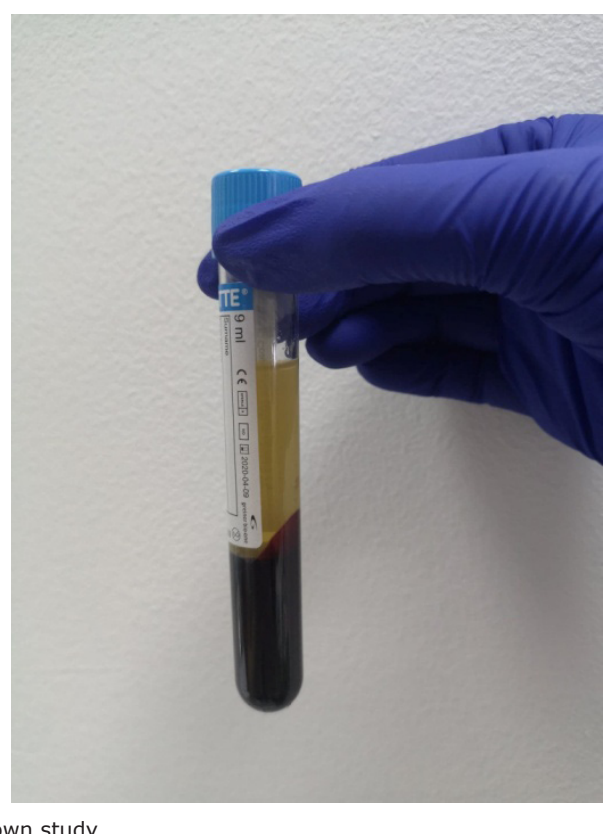

Source: own study

Figure 2. The patient's collected blood after centrifugation in a centrifuge designed for platelet-rich plasma

\section{Treatment procedure}

From a test tube with centrifuged blood, the specialist takes highly concentrated platelets (they constitute about $20 \%$ of its content) into a syringe and applies them on the treatment area, mainly by injection (as mesotherapy or linearly along a fold or wrinkle) or with a mask [5]. The second method of regeneration is prepared by pouring the plasma on a paper mask or on a mask made of bionanocellulose (a substance supporting the transport of active ingredients with moisturizing and antibacterial properties) and then the whole item is applied to the treatment area $[5,6]$. Injection methods, on the other hand, can be performed under 
ultrasound or X-ray control. The material is also applied with various types of activators or in a combination of a platelet concentrate with allogeneic or own bone grafts or with bone marrow cells $[8,9]$. The process of preparing platelet-rich plasma for the procedure takes about twenty minutes, and the time of application of the preparation is 10 to 15 minutes $[1,6]$.

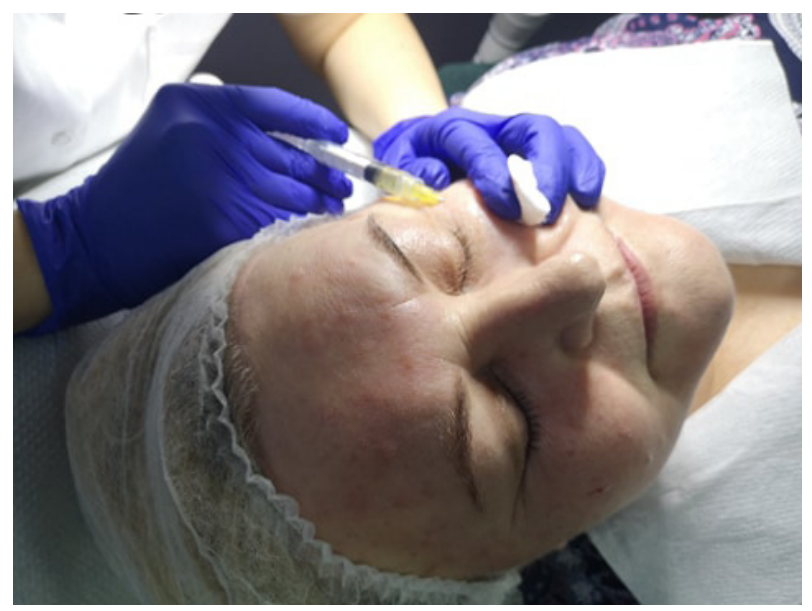

Source: own study

Figure 3. Administration of platelet-rich plasma by injection

\section{Cell composition analysis}

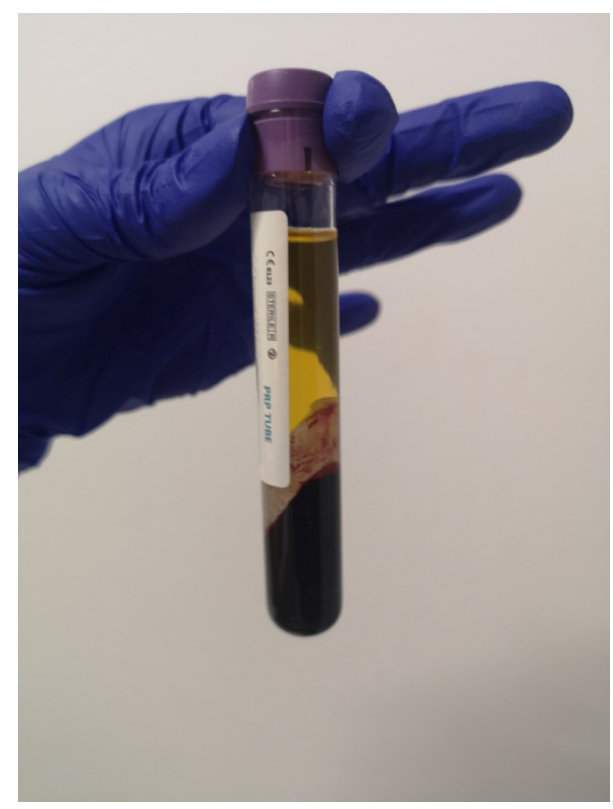

Source: own study

Figure 4. Another patient's blood after centrifugation - a larger platelet-rich buffy coat visible

A standard blood sample contains only $1 \%$ of white blood cells and $6 \%$ of the desired thrombocytes - most of these are erythrocytes ( $93 \%$ of the sample). The idea of the treatment is to reverse the ratio of these morphotic blood elements - reducing the volume of red blood cells to 5\% and increasing the concentration of platelets to $94 \%$ (the effectiveness of the treatment will be achieved with a fivefold increase in their concentration). Even an eight-fold or eleven-fold increase in the concentration of thrombocytes can be obtained $[3,4]$. Their concentration in PRP should not be less than $200 \%$ of the number of thrombocytes of the output blood. As a rule, the higher the concentration of PLT, the better the quality of preparation. However, there are studies showing that too high concentration of thrombocytes in PRP inhibits the regeneration process [6,9-11].

Plasma consists of concentrated platelets and leukocytes. It is from them, after prior activation, that signaling proteins and growth factors are released: PDGF (plateletderived growth factor), IGF (insulin-like growth factor), FGF (fibroblast growth factor), TGF (transforming growth factor), VEGF (vascular endothelial growth factor) or EGF (epidermal growth factor), as well as fibrinogen, vitronectin, fibrin, or fibronectin and thrombospodin $[3,4,10]$. Other substances released from platelets are vitamins, oxidative enzymes and oligopeptides. Growth factors are also found in stem cells and connective tissue cells. They are signal substances for the correct reconstruction processes. By way of these ingredients, tissue regeneration occurs. The whole mechanism is similar to the healing process $[6,9,11]$. TGF and PDGF stabilize damaged tissue in the first stages of regeneration. The former stimulates DNA synthesis, as well as cell proliferation and differentiation, and stimulates fibroblasts. The latter deals mainly with stimulating the synthesis of the intercellular matrix and the differentiation of mesenchymal stem cells. IGF accelerates healing in tendons, and VEGF and FGF stimulate angiogenesis $[1,2]$.

\section{Mechanism of action of platelet-rich plasma}

The desired material - i.e. mainly platelets (thrombocytes) - is formed by the fragmentation of megakaryocytes in the bone marrow. In this manner, blood vessels proliferate and are rebuilt, and tissues are repaired and regenerated [3]. However, through the formation of new vessels and the presence of chemokines secreted by activated platelets and leukocytes, there appear macrophages which release their growth factors and cytokines, which stimulates further regeneration $[1,12]$. Thus, after the activation of thrombocytes, huge amounts of biologically active substances are released. This is most intense in the first hours after activation [3]. The secretion of growth factors begins a few minutes after the start of the physiological coagulation process following the injection. The first hour guarantees the secretion of about $90 \%$ of factors. Additional growth factors are secreted for the next 7 days after the procedure by way of the presence of mRNA in platelets [8]. After this time, macrophages take over the stimulation of regenerative processes [5]. Among the biologically active substances, the elements having the greatest impact on the regeneration process are precisely the growth factors that are stored mainly in the alpha granules of thrombocytes, the cytoplasm of thrombocytes and the dense granules or lysosomes [3]. They are there in an inactive form, and their activation occurs as a result of the activation of platelets $[1,12]$. Growth factors secreted from thrombocytes, apart from influencing the blood coagulation process, are also important in the processes of migration and proliferation of cells: fibroblasts, myocytes, chondrocytes, osteoblasts, tenocytes, endothelial cells of blood vessels and mesenchymal cells [3]. Through such components, epidermal cells differentiate and their multiplication is intensely stimulated. Moreover, angiogenesis and synthesis of extracellular matrix components 
are enhanced. The effect of these phenomena is remodelling and increased regeneration in the area of the dermis and subcutaneous tissue [9]. When the thrombocyte is activated, it releases growth factors that are attached to the receptors of target cells. These include fibroblasts, mesenchymal stem cells or epithelial cells. As a result of cytokine stimulation, the processes of angiogenesis, chemotaxis, revascularization and immunomodulation are activated. One-time binding of the thrombocyte to the transmembrane receptor activates the signaling protein, the expression of the gene sequence then takes place, which causes cell proliferation, collagen and matrix synthesis, or osteoid production $[8,13]$.

Scientists have also shown the presence of peptides in blood platelets that have antibacterial properties. Other properties include analgesic or anti-inflammatory effects, which have been confirmed in clinical and experimental studies $[3,14]$. Due to the platelet-rich plasma, capillary bleeding is limited and angiogenesis or endothelial development is stimulated when used intraoperatively during the surgical correction of wrinkles or in procedures reducing the effects of skin photoaging. Other benefits include reducing the duration of surgical procedures, minimising the risk of complications and increasing the likelihood of a skin graft acceptance. Moreover, the autologous material in question exhibits high anti-radical properties [8].

\section{Types of PRP}

In medicine, there are two forms of platelet-rich plasma used: inactivated and activated. The former is activated at the injection site - the very micro-damage to the skin or contact with collagen stimulates regenerative processes, thanks to the factors contained in the tissues. The form employed also determines the speed of the release of beneficial components of the autologous material, which is important for the functioning of cells more sensitive to its action $[3,6]$. In the "natural" activation, the factors are released more slowly and gradually, which favours longer exposure to a constant concentration of these factors [1]. We can activate exogenously platelet-rich plasma by adding calcium chloride or bovine thrombin, as well as by freezing or using TRAP-6 (a synthetic thrombin-like peptide). More growth factors will then be released and the process will be much faster. However, the literature suggests that there is no need to activate PRP before administering it to the patient $[3,11]$.

\section{Application in aesthetic medicine}

This revolutionary method is employed in both dermatology and aesthetic medicine. The preparation is used, among others, for tissue biostimulation and its regeneration after procedures in these areas. Surgical face-lifting can be mentioned as an example. Platelet-rich plasma is also employed as an alternative to tissue fillers, and in a procedure such as lipofilling, it is combined with autologous adipose tissue. Such a combination has a filling and stimulating effect, and the volume effect in soft tissues remains longer [2,5,12].

The beneficial effects of PRP take place in the synthesis of type III and IV collagen, which is applied to improve hydration, skin reconstruction and rejuvenation, but also in the treatment of wounds, including those difficult to heal, and in reconstructive medicine $[1,5,8,15]$. Wounds such as diabetic foot ulcers or burns are also indications for platelet-rich plasma therapy [3]. This material has found particular application in the treatment of chronic and acute muscle inflammation, tendinitis, muscle fibrosis or damage to certain joints. Interestingly, the procedures with the use of platelet-rich plasma are harnessed not only in human medicine, but also in veterinary medicine, mainly in the treatment of dogs and horses $[3,8]$.

Platelet-rich plasma is unequivocally considered to be an important element of regenerative medicine, in particular, in skin rejuvenation, anti-aging effects and in procedures to reduce the visibility of scars. The skin regains vitality and youth, and it is smoother and more elastic [12]. PRP has also been employed in the correction of the aesthetics of the eye area, intimate places, hands, and in treatment of diseases such as eczema, acne, vitiligo, atrophy and hyperpigmentation. PRP is also used in androgenic alopecia, which occurs in both women and men. The administered preparation inhibits hair loss and is effective in preventing this process. The preparation is also applied to reduce wrinkles and stretch marks, to moisturize the skin and increase its tension $[5,6]$. The literature indicates a thickening of the living layer of the epidermis after the application of platelet-rich plasma, and the skin, after its administration, is characterized by a more ordered structure of collagen fibres than before the treatment. This autologous material significantly shortens the regeneration time after invasive aesthetic medicine procedures and improves the aesthetic effect of other treatments $[2,4,6,16]$.

\section{Effectiveness, safety and treatment effects}

PRP therapy appeared thanks to research on tissue regeneration and wound healing [9]. The beginnings of regeneration thanks to own cells date back to the 1970s, when autologous platelet-rich plasma was obtained in the process of multi-component apheresis as a by-product $[5,8]$. The first procedure was performed in 1987 and it was a cardiac surgery [1]. The literature indicates that platelet-rich plasma began to be more widely applied in the nineties of the twentieth century, and in 2003 it gained popularity in aesthetic medicine. PRP is a safe preparation, primarily because it is not a substance foreign to the body $[3,5,12]$. Moreover, autologous materials eliminate the risk of allergic reactions, which are the most common complications in the treatment with antigen-foreign protein. There is also a negligible possibility of transmitting blood-borne infectious diseases to the body (including HIV, hepatitis B, hepatitis C) $[9,13,15]$. It is a $100 \%$ biocompatible product. The entire mechanism of skin regeneration and revitalization with bioactive plasma using growth factors is called ACR (Autologus Cellular Regeneration). It is known that the discussed blood plasma components activate naturally in the event of skin damage, so the procedure stimulates biological regenerative processes $[2,12]$.

The elements that determine the rejuvenating effect of the treatment and its effectiveness are: appropriate centrifuge (better effects will be achieved by a horizontal centrifuge than an angular centrifuge), appropriate centrifugation speed (it should not be too slow, because there will be no phase separation, nor too fast, because the platelets will be 
damaged), the ability to collect the appropriate phase, and thus the selection of the appropriate tube of the right shape, certified and safe. It is also important not to draw too much plasma - then the dilution of the platelets will be too strong and the procedure will be less effective [6].

However, one should remember about the contraindications to using the treatment. The most frequently mentioned here are: cancer, pregnancy and lactation, blood diseases, thrombocytopenia, hemodynamic instability, fibrinogen deficiency, or platelet dysfunction syndromes, chronic liver diseases, metabolic, systemic and autoimmune diseases, thrombotic treatment, tendency to scarring, skin allergies, active skin inflammations, viral and bacterial infections, sepsis, acute and chronic infections, and even a cold, antibiotic therapy and taking aspirin $[8,12,16]$. It is absolutely necessary to maintain sterility during the procedure and observe the basic rules of hygiene, as they are one of the few risks in plasma therapy. Others include: the use of an uncertified kit or improper administration of the preparation [6)].

The indications include in particular: hair loss, androgenic alopecia, scars, stretch marks, eczema, acne, atrophy, vitiligo, skin in need of revitalization, skin laxity, visible signs of aging, condition after aesthetic medicine treatments, people at risk of allergies, patients who do not want synthetic fillers, improving the healing of skin lesions $[2,12,15]$.

The platelet-rich plasma therapy for the eye area should be applied every 2 weeks, and the recommended number of treatments is 2 to 4 , depending on the goals of the treatment. Then, reminding treatments are performed 1-2 times a year. In the area of the scalp, the treatments are repeated 5-7 times every 14 days. In the remaining areas, the procedure should be carried out every 7-14 days. The series should consist of 4 to 5 meetings, and to maintain the effects, it is recommended to perform 1 treatment at an interval of 12-16 weeks. The effects are noticeable during the first series [5,17]. Patients over 20 and 30 are often satisfied with a single treatment with platelet-rich plasma to revitalize the skin. However, after the age of 40, several approaches or combination therapies should be performed. Moreover, plasma effectively prepares the skin for other treatments in the field of cosmetology and aesthetic medicine [6].

\section{Challenges}

According to Maria Noszczyk and Anita TarajkowskaOlejnik, 12 months after the injection, fibroblast proliferation and physiological regenerative processes are stimulated, and the production of type III and IV collagen increases, which is confirmed by the results of histological tests [4]. They also believe that the platelet-rich plasma injection will be one of the most popular treatments in the coming years, especially in the prevention of skin aging [4]. Other authors also emphasize the timelessness and universality of PRP therapy, which, thanks to its high safety, is an alternative to other treatments for people prone to allergies. It is also characterized by high efficiency, documented by numerous studies on the use of the autologous material of the organism [1].

\section{Limitations}

One of the limitations for platelet-rich plasma therapy is the lack of specific and standardized methods of substitute production or guidelines on the method of administration, as well as subsequent rehabilitation, which carries a high risk of abuse [1]. This may be evidenced by the fact that there are reservations as to the safety of application of PRP. There is scientific evidence that there is little or no specific benefit from such therapy. However, the level of this evidence is low, and the market still lacks randomized trials, despite the fairly extensive documentation of PRP $[4,6]$. According to M. Wasiluk, it is not possible. The lack of effects of PRP therapy is, however, often the result of improper collection of platelet-rich or even platelet-poor plasma in the lack of awareness of the doctor performing the procedure. Another reason is to propose the described therapy for skin problems that require a combined treatment or a completely different method of treatment and elimination of aesthetic defects, as in the case of nasolabial furrows [6].

\section{CONCLUSION}

PRP has enormous regenerative and biostimulating benefits for the skin. It stimulates cells to angiogenesis, differentiation, proliferation and synthesis of essential components for remodelling of the treated area [9]. Platelet-rich plasma is very popular among scientists, doctors and cosmetologists. In aesthetic medicine, it has a number of applications, ranging from accelerating the healing of skin damage, through scar reduction, treatment of hair loss, to rejuvenation and improvement of skin aesthetics $[2,3,12,15]$. However, despite the enormous amount of scientific knowledge, many questions remain, mainly in the context of platelet-rich plasma treatment, hence the need for further research exploring the possibility of a wider application of this autologous material [3].

\section{ORCID iDs}

Anna Lichtarska (Dhttps://orcid.org/0000-0003-3887-8719 Małgorzata Sokół (1)https://orcid.org/0000-0002-3901-515X

\section{REFERNCES}

1. Gołos A, Treliński J. Kliniczne zastosowanie osocza bogatopłytkowego. Hematologia. 2014;5(3):252-4.

2. Galicka E. Zabiegi odmładzające twarz (Osocze bogatopłytkowe). In: A. Przylipiak (ed). Podstawy Medycyny Estetycznej. Białystok: KAW; 2014:45-47.

3. Prządka P, Kiełbowicz Z, Skrzypczak P. Autogenne osocze bogatopłytkowe - rodzaje, sposoby aktywacji i zastosowanie. Med Weter. 2016;72(7):403-6.

4. Tysiąc-Miśta M, Gruca O, Bulanda S, Trzeciak H, Wyszyńska M, Kasperski J. The use of platelet-rich plasma in medicine with particular reference to dentistry and aesthetic medicine. Protet Stomatol. 2019;69(3):271-3.

5. Kępa A. Zabiegi z zakresu medycyny estetycznej na okolice oczu przegląd wybranych technik. Cz. II. ACM. 2015;4(4):370-71.

6. Wasiluk M. Medycyna estetyczna bez tajemnic. Warszawa: PZWL; 2016:145-53. 
7. Kołaczek A. Przegląd metod pielęgnacji skóry dojrzałej. ACM. 2015;6(4):543.

8. Aleksiewicz R, Starczewska I, Kostrzewski M. Autologiczne osocze bogatopłytkowe - możliwości i zastosowania klinicznego. Med Weter. 2015;71(5):276-8, 280.

9. Noszczyk M, Tarajkowska-Olejnik A. Zabiegi z zastosowaniem tkanek autologicznych. In: M. Noszczyk M (ed). Kosmetologia pielegnacyjna i lekarska. Warszawa: PZWL; 2018:328.

10. Stanirowski P, Sawicki W. Nowoczesne metody terapii trudno gojących się położniczo-ginekologicznych ran pooperacyjnych analiza przydatności i skuteczności stosowania. Post Nauk Med. 2013;26(7):479.

11. Lachert E, Antoniewicz-Papis J, Pogłód R. Nowe spojrzenie na zastosowanie składników krwi. J Transf Med. 2012;5(3):124.
12. Kurek M. Osocze bogatopłytkowe a proces starzenia się skóry. Puls Uczelni. 2012;6(1):9-10.

13. Padlewska K. Kosmetologia ciała. Warszawa: PZWL; 2018:422.

14. Mohammed A, Ahmed M, Hussam EA, Ayaj M, Ismael A. Leczenie choroby zwyrodnieniowej stawu biodrowego przy zastosowaniu iniekcji osocza bogatopłytkowego pod kontrolą ultrasonograficzną: systematyczny przegląd piśmiennictwa. J Ultrason. 2018;18:336.

15. Puri N. Platelet rich plasma in dermatology and aesthetic medicine. Our Dermatology Online. 2015;6(2):210.

16. Klonowska J. Mezoterapia igłowa skóry głowy osoczem bogatopłytkowym jako metoda redukcji nadmiernego wypadania włosów. ACM. 2017;6(6):614-5.

17. Padlewska K. Medycyna estetyczna i kosmetologia. Warszawa: PZWL; 2014:235. 